\title{
Amelioration of Pterostilbene Antiproliferative, Proapoptotic, and Oxidant Potentials in Human Breast Cancer MCF7 Cells Using Zein Nanocomposites
}

\author{
Hussam I Kutbi ' \\ Ahmed K Kammoun ${ }^{2}$ \\ Dalia Farag El-Telbany ${ }^{3}$ \\ 'Department of Pharmacy Practice, \\ Faculty of Pharmacy, King Abdulaziz \\ University, Jeddah, 21589, Saudi Arabia; \\ ${ }^{2}$ Department of Pharmaceutical \\ Chemistry, Faculty of Pharmacy, King \\ Abdulaziz University, Jeddah, 21589, \\ Saudi Arabia; ${ }^{3}$ Department of \\ Pharmaceutics, Faculty of Pharmacy, \\ Modern University for Technology and \\ Information (MTI), Cairo, II57I, Egypt
}

Correspondence: Dalia Farag El-Telbany Department of Pharmaceutics, Faculty of Pharmacy, Modern University for Technology and Information (MTI) University, El-Hadaba El-Wosta, 5th District, Mokatam, Cairo, II57I, Egypt

Tel +20-II-1996-6617

Fax+20227294500

Email dalia.altelbany@gmail.com
Purpose: This study aimed to explain the influence of zein nanosphere (ZN NS) formulation on the pharmacotherapeutic profile of PTS in MCF7 cells.

Methods: Liquid-liquid phase separation was used to formulate PTS-ZN NSs. The formulations developed were evaluated for particle-size analysis, encapsulation efficiency, and in vitro diffusion. Also, assays of cytotoxicity, uptake, cell-cycle progression, annexin V, apoptotic gene mRNA expression and biochemical assays were carried out.

Results: The PTS-ZN NS formulation selected showed $104.5 \pm 6.2 \mathrm{~nm}, 33.4 \pm 1.8 \mathrm{mV}, 95.1 \%$ $\pm 3.6 \%$, and $89.1 \% \pm 2.65 \%$ average particle size, zeta-potential, encapsulation efficiency and in vitro diffusion, respectively. With $\mathrm{MCF} 7$ cells, $\mathrm{IC}_{50}$ was reduced approximately 15 -fold, with increased cellular uptake, accumulation in the $\mathrm{G}_{2} / \mathrm{M}$ phase, increased percentage of cells in the pre- $\mathrm{G}_{1}$ phase, amelioration of early and late apoptosis, raised mRNA expression of CASP3 and CASP7, lower expression of cyclin-CDK1, and enhanced oxidant potential through decreased glutathione reductase (GR) activity, and enhanced reactive oxygen-species generation and lipid-peroxidation products.

Conclusion: PTS-ZN NSs indicated enhanced antiproliferative, proapoptotic, and oxidant potential toward MCF7 cells compared to free PTS. Ameliorated results of nanosized carriers, cellular uptake, and sustained diffusion may contribute to these outcomes.

Keywords: phototherapy, pterostilbene, MCF7 cells, nanospheres, zein

\section{Introduction}

Tumor resistance to traditional pharmaceuticals is a critical problem in cancer therapy. In particular, resistance to apoptosis enables tumor cells to evade innate surveillance mechanisms and disturb intracellular signaling cascades to initiate tumor promotion and metastasis. Disturbance of apoptotic pathways may render cancer cells resistant to treatment and promote tumorigenesis. It is widely considered that apoptosis evasion is a distinct property of cancer. ${ }^{1}$ Enhancement of apoptosis has become a focus of research in the last few decades to improve clinical management of cancer. While limiting concurrent damage to normal cells, apoptosis stimulation in tumor cells is a major weapon. ${ }^{2}$ Also, inhibition of apoptotic responses could be the main reason for both treatment resistance and with exclusion of considering apoptosis is the main mechanism of anticancer action. ${ }^{3}$ Desirable tumor response is controlling apoptosis inducement with anticancer compounds. ${ }^{4}$ High mortality rates were exaggerated due to 
tumor resistance, resulting in women worldwide being threatened with elevated risk of developing breast cancer. Breast cancer was rated $>90 \%$ in 5-year survival rates for localized diseases. $^{5,6}$

With reduced adverse side effects, the potential of natural molecules to manipulate cancer pathways to enhance apoptosis constitutes an important approach in global cancer confrontation. ${ }^{7}$ Pterostilbene (PTS; trans-3,5-dimethoxy-4hydroxystilbene) was originally identified in the leaves of the grape vine, (Vitis vinifera), of sandalwood (Pterocarpus santalinus) heartwood(Pterocarpus marsupium), and the bark of Guibourtia tessmannii. ${ }^{8}$ Anticarcinogenic properties of PTS are mainly correlated with its antioxidant activity. PTS enhances oxidative stress in breast cancer. ${ }^{9,10}$ PTS is also present in blueberries. ${ }^{11}$ PTS's therapeutic profile has been studied in breast, prostate, lung, and colorectal cancers.

Establishment of effective treatment strategies based on a deep understanding of molecular drug-resistance mechanisms is much needed. Pharmaceutical nanotechnology has significant potential to enhance chemopreventive profiles of therapeutics and anticancer-molecule delivery. ${ }^{12-14}$ Nanobiomedicine has attained therapeutic outcomes in fighting cancer. Therapeutic delivery is the main objective of nanomedicine, and is utilized in cancer therapy with promising variant methodologies. ${ }^{15-18}$ Nanostructured safe histocompatible carriers loaded with phytotherapeutics support the amelioration of cancer and other diseases. ${ }^{19}$ Nanoparticles offer significant enhancements in drug delivery, and contribute significantly to pharmacotherapy with loaded active molecules. ${ }^{19}$

Green synthesis of natural polymers for biomedical application is global recommendation by virtue of its minimized toxicity, recyclable properties, ${ }^{20}$ sustainable purposes, and economic trends. $^{21,22}$ Zein nanospheres (ZN NSs) are promising delivery systems because of their plant provenance and process of preparation. $\mathrm{ZN}$ is obtained from corn ${ }^{23}$ and is safe, non-toxic, FDA-approved, histocompatible, and does not inducing celiac disease or autoimmune responses. ${ }^{22,24,25}$

The aim of the current study was to investigate the potential of a PTS-ZN NSs formulation in ameliorating cytotoxicity proapoptotic and oxidative stress MCF7 cells.

\section{Methods}

\section{Materials}

PTS, ZN, and ethanol were purchased from SigmaAldrich. Solvents used were of analytical grade. Deionized water was used for preparation of the solutions.

\section{Preparation of PTS-ZN NSs}

Five PTS-ZN NS (P1-P5) formulations were prepared by liquid-liquid phase separation ${ }^{19,25,26}$ to diminish the use of solvents. The PTS formulations were developed using PTS-ZN ratios of 5:1, 3:1,1:1, 1:3, and 1:5, respectively. PTS and ZN were dissolved in $10 \mathrm{~mL}$ of $85 \%$ ethanol with the aid of a vortex (ZX3; Velp Scientifica, Usmate Velate, Italy) and ultrasonic probe (Vibra-Cell VCX750; Sonics and Materials, Newtown, CT, USA). The solution obtained was poured into deionized water. The mixture was the subjected to 3 hours of $2,000 \mathrm{rpm}$ magnetic stirring at room temperature to vaporize ethanol content. Then, the dispersion generated was subjected to centrifugation at $20,000 \mathrm{~g}$ speed, followed by freeze-drying, where trehalose was utilized as a cryoprotectant.

\section{Evaluation of PTS-ZN NSs}

Particle-Size, zeta-Potential, and Polydispersity Index Average particle-size, zeta-potential, and polydispersityindex values of the formulations were calculated using laser diffraction. Samples were prepared in disposable cuvettes by adding $1 \mathrm{~mL}$ to deionized water.

\section{Nanocomposite-Surface Morphology}

The surface morphology of the formulations was investigated using SEM (JEM 100-CX; JEOL, Tokyo, Japan). Formulations were coated with gold under vacuum after being affixed on metal stubs.

\section{Encapsulation Efficiency}

Samples were dissolved in ethanol, filtered using $0.22 \mu \mathrm{m}$ filters, then analyzed based on an HPLC method. ${ }^{27}$ PTSencapsulation efficiency (w/w\%) was calculated:

$$
\frac{\text { amount of PTS in the nanospheres }}{\text { amount of initially added PTS }} \times 100
$$

\section{In Vitro Diffusion}

An automated Franz diffusion-cell apparatus (MicroettePlus; Hanson Research, Chatsworth, CA, USA) using $0.45 \mu \mathrm{m}$ synthetic nylon membrane (Pall, Port Washington, NY, USA) was used to measure PTS diffusion obtained from the formulations. ${ }^{28}$ At a temperature of $37^{\circ} \mathrm{C} \pm 0.5^{\circ} \mathrm{C}$, samples were positioned between donor and receptor compartments. PBS (0.01 M, pH 7) was used as diffusion medium and stirred at $400 \mathrm{rpm}$. An autosampler was used to withdraw samples at $0.25,0.5,1$, $2,4,8,12,18,24$, and 36 hours, which were analyzed for PTS content with HPLC (Agilent 1200; Agilent Technologies, Santa Clara, CA, USA). ${ }^{27}$ 


\section{Cell Culture}

Two cell lines were utilized - MCF7 and MDA-MB231. They were purchased from the International Center for Training and Advanced Research (Cairo, Egypt) and supplied by the American Type Culture Collection (Manassas, VA, USA). EMEM was used for MCF7-cell culture. Leibovitz's medium was used for MDA-MB231-cell culture and supplemented with 10\% FBS, penicillin (100 U/ $\mathrm{mL})$ and streptomycin $(100 \mathrm{mg} / \mathrm{mL})$. Cells were incubated at $37^{\circ} \mathrm{C}$ in a humidified $5 \% \mathrm{CO}_{2}$ atmosphere (Thermo Fisher Scientific Forma series II 3141) using culture plates and flasks (SPL Life Sciences). Inverted microscopy (Axiovert 40-CFL; Zeiss, Göttingen, Germany) was used to examine cells.

\section{Cytotoxicity}

At a density of $2 \times 10^{3}$ cells/well, 96-well plateswere used to estimate cytotoxicity activity by seeding MCF7 and MDA-MB231 cells according to MTT-assay and Abcam (Cambridge, UK) kits. PTS, ZN, and an equivalent amount of PTS-ZN NSs were incubated in a $\mathrm{CO}_{2}$ incubator at $37^{\circ}$ $\mathrm{C}$ for 48 hours, applying concentration ranges with reference to PTS at logarithmic intervals.

\section{Cell-Uptake Analysis}

In the presence of $5 \% \mathrm{CO}_{2}$ at $37^{\circ} \mathrm{C}$ and at a density of $10^{5}$ cells/dish, MCF7 cells were treated with $\mathrm{IC}_{50}$ values of PTS and and an equivalent concentration of PTS-ZN NSs, then incubated for 2 and 4 hours. PBS was used to wash the monolayers, then a lysis solution (PBS containing $0.025 \%$ trypsin and $1 \%$ Tween 20 ) was added and the mixture left for 30 minutes at $37^{\circ} \mathrm{C}$. Cell-lysate aliquots were analyzed using HPLC.

\section{Cell Cycle-Progression Analysis}

MCF7 cells $\left(5 \times 10^{3}\right.$ MCF7 cells/well) were seeded for 36 hours in six-well cell-culture plates after treatment with the $\mathrm{IC}_{50}$ of PTS, ZN, and equivalent concentration of PTSZN NSs. An assay was carried out utilizing a CycleTest Plus DNA-reagent kit (Becton Dickinson, San Jose, CA, USA). Samples DNA index were analyzed in reference to cells with already determined DNA content.

\section{Annexin $\vee$ Assay}

MCF7 cells $\left(5 \times 10^{3}\right.$ well) were incubated for 36 hours in a six-well plate after treatment with the $\mathrm{IC}_{50}$ of PTS, ZN, and PTS-ZN NSs using dual staining (BD Biosciences). Cells were centrifuged and resuspended in $500 \mu \mathrm{L} 1 \times$ binding buffer. After that, we added $5 \mu \mathrm{L}$ each of annexin $\mathrm{V}$-FITC and propidium iodide (BD Biosciences) at room temperature for 5 minutes to be kept in dark flow cytometry (FACS Calibur, BD Bioscience) applied.

\section{mRNA Expression of Apoptosis-Related Genes}

RT-PCR was used for this analysis. Using a Qiagen RNeasy mini kit, mRNA extraction from MCF7 cells was carried out. Reverse transcription with a SuperScript III cDNA-synthesis system (Invitrogen, UK) of cDNA proceeded in a $20 \mu \mathrm{L}$ reaction mix. Table 1 displays the primer sequences related to $C A S P 3, C A S P 7$, and $C D K 1$. $A C T B$ was used as the housekeeping gene. Relative expression was obtained with $1 \mu \mathrm{L}$ synthesized cDNA (10 ng/ $\mu \mathrm{L})$ as the template in $5 \mu \mathrm{L}$ PowerUp SYBR green PCR master mix and $0.75 \mu \mathrm{L}$ of each primer utilizing an Applied Biosystems 7500 RT-PCR system. Relative quantification $\left(\Delta \Delta \mathrm{C}_{\mathrm{t}}\right)$ was used.

Table I Primer sequences used for mRNA expression of apoptosis-related genes using RT-PCR

\begin{tabular}{|l|l|l|}
\hline \multicolumn{2}{|l|}{} & Sequence (5'-3') \\
\hline CASP3 & $\begin{array}{l}\text { Forward primer } \\
\text { Reverse primer }\end{array}$ & $\begin{array}{l}\text { TTC ATT ATT CAG GCC TGC CGA GG } \\
\text { TTC TGA CAG GCC ATG TCA TCC TCA }\end{array}$ \\
\hline CASP7 & $\begin{array}{l}\text { Forward primer } \\
\text { Reverse primer }\end{array}$ & $\begin{array}{l}\text { GGACCGAGTGCCCACTTATC } \\
\text { TCGCTTTGTCGAAGTTCTTGTT }\end{array}$ \\
\hline CDKI & $\begin{array}{l}\text { Forward primer } \\
\text { Reverse primer }\end{array}$ & $\begin{array}{l}\text { TGGATCTGAAGAAATACTTGGATTCTA } \\
\text { CAATCCCCTGTAGGATTTGG }\end{array}$ \\
\hline ACTB & $\begin{array}{l}\text { Forward primer } \\
\text { Reverse primer }\end{array}$ & $\begin{array}{l}\text { TCCGTCGCCGGTCCACACCC } \\
\text { TCACCAACTGGGACGATATG }\end{array}$ \\
\hline
\end{tabular}




\section{GR-Enzyme Assay}

Abcam kits (Cambridge, UK) and a microplate reader were used for this assay. GR was calculated for PTS, $\mathrm{ZN}$, and PTS-ZN NS samples to measure oxidative stress. MCF7 cells were inoculated into six-well plates at $10^{6}$ cells $/ \mathrm{mL}$ and treated with the $\mathrm{IC}_{50}$ of formulations for 48 hours. PBS was used to wash cells after harvesting. GR content was analyzed with cell extract-absorbance measurement at $412 \mathrm{~nm}$.

\section{ROS and MDA Assays}

At a cell density of $5 \times 10^{3} /$ well in 96 -well plates, MCF7 cells were treated with the $\mathrm{IC}_{50}$ of PTS, ZN, and PTS-ZN NSs for 48 hours, after which $10 \mu \mathrm{M}$ 2.7-dichlorofluorescein diacetate was applied for cell staining for 45 minutes using the Abcam kits. A lipid peroxidation-assay kit (BioVision, Milpitas, CA, USA) was used to estimate cellular MDA content.

\section{Serum Stability}

Colloidal stability of PTS-ZN NSs was evaluated in FBS (Thermo Fisher Scientific). ${ }^{29}$ PTS-ZN NS suspensions (200 $\mu \mathrm{L}$ ) were added to $1 \mathrm{~mL} 70 \%$ FBS, then subjected to 48 hours' incubation at $37^{\circ} \mathrm{C}$, followed by $600 \mathrm{rpm}$ stirring. At selected incubation times, samples were withdrawn and evaluated for average particle size.

\section{Statistical Analysis}

Data are presented as means \pm SD of at least three independent experiments. Student's $t$-test or one-way ANOVA followed by Tukey's test was used, and two-tailed $p<0.05$ was taken as significant. The software used was SPSS.

\section{Results and Discussion}

The present study aimed to generate a ZN-based nanodelivery system for PTS with enhanced antiproliferative, proapoptotic, and oxidative stress potentials in MCF7 cells. To address the problem ofresistance to cancer therapies due to apoptosis failure, the promising natural molecule PTS is recommended for its anticancer potential in breast cancer treatment. The exerted potential via intracellular mechanisms is a promising augmentation for supporting apoptosis. The development of nanocomposites to optimize the antitumor potential of PTS is recommended.

\section{Evaluation of PTS-ZN NSs}

In this study, we opted to fabricate a potential delivery system utilizing a biocompatible natural plant-derived drug and polymer instead of synthetic biomaterials. Plant-derived biomaterials are preferred to even animal-origin candidates by virtue of the absence of infection risk, contamination with biological vehicles, and possibility of prion infection or religious concerns. ${ }^{30}$ It was logical to use liquid-liquid phase separation to reduce the need for variant chemical reagents and cross-linkers, in order to avoid possible toxicity and accumulation in the fabricated nanocomposites. Also, this enhances the use of sustainable resources.

PTS was fabricated as ZN NSs in five formulations; P1, P2, P3, P4 and P5. Table 2 displays the characteristics of PTS nanocomposites formulation. The obtained reduced average particle size in P5 formula $(104.5 \pm 6.2 \mathrm{n})$ was recommended for suggested enhanced absorption and residence time in biological systems. ${ }^{24}$ The generated reduction in particle size could be associated to $\mathrm{ZN}$ percent raising in the formulation. This was in accordance with the enlarge in obtained particle size of P1 formula where the reduced quantity of PTS attained on nanocomposites exterior surface. Enhanced interfacial tension between aqueous medium and particle surface could be induced which contribute to increased particle diameter. ${ }^{25} \mathrm{P} 1$ formula showed the largest magnitude of zeta-potential (33.4 $\pm 1.8 \mathrm{mV}$ ) and the least magnitude of polydispersity index $(0.16 \pm 0.01)$. Zeta-potential value indicates the potential stability of the developed nanostructures. Nanoparticles obtained $\pm 30 \mathrm{mV}$ zeta-potential have been recognized stable in suspension, as surface charge prevents agglomeration of formulated nanostructures. ${ }^{26}$ Regarding to encapsulation efficiency, P5 showed 95.1 $\pm 3.6 \%$

Table 2 PTS-ZN NS particle-size analysis and encapsulation efficiency

\begin{tabular}{|l|c|c|c|c|c|}
\hline Formula & PTS:ZN ratio & Mean particle size (nm) & Zeta-potential (mV) & Polydispersity index & Encapsulation efficiency (\%) \\
\hline PI & $5: 1$ & $246.4 \pm 18.1$ & $22.6 \pm 1.8$ & $0.67 \pm 0.02$ & $81.4 \pm 4.9$ \\
P2 & $3: 1$ & $173.2 \pm 12.4$ & $19.2 \pm 1.3$ & $0.51 \pm 0.01$ & $87.6 \pm 2.8$ \\
P3 & $1: 1$ & $158.8 \pm 11.2$ & $31.4 \pm 1.2$ & $0.38 \pm 0.02$ & $88.3 \pm 2.3$ \\
P4 & $1: 3$ & $108.1 \pm 5.9$ & $33.1 \pm 0.9$ & $0.42 \pm 0.02$ & $90.7 \pm 4.1$ \\
P5 & $1: 5$ & $104.5 \pm 6.2$ & $33.4 \pm 1.8$ & $0.16 \pm 0.01$ & $95.1 \pm 3.6$ \\
\hline
\end{tabular}




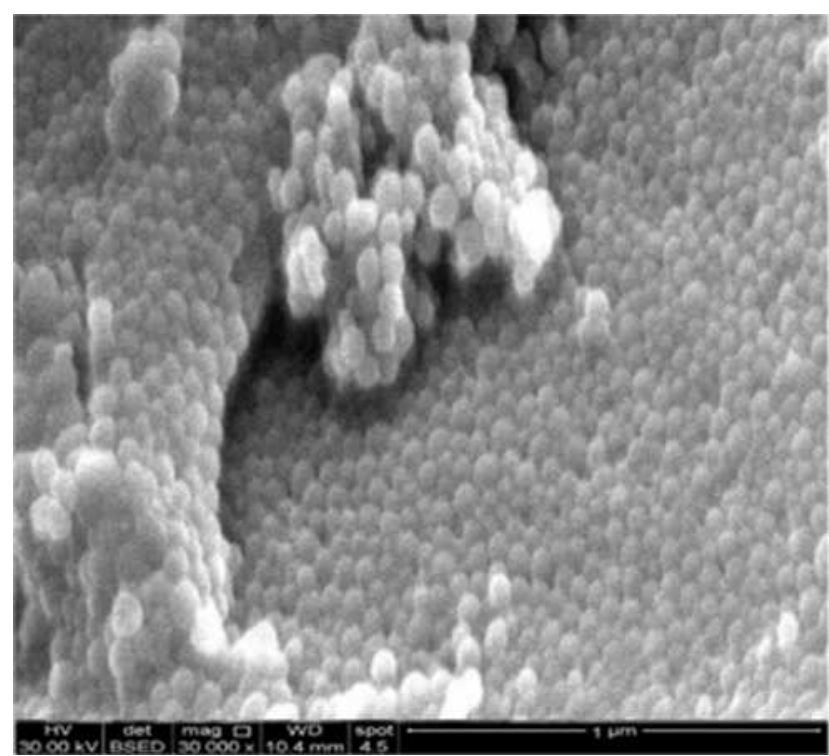

Figure I SEM of PTS-ZN NSs (P5 formula).

encapsulation efficiency as the highest results. This could be explained ${ }^{31}$ as the binding affinity of PTS on ZN increased with the raise of their polymerization degree. The capacity of nanoparticles to enclose elevated amounts of payloads was already investigated. ${ }^{19,24,25,32}$ The utilized method of formulation was successful in obtaining high encapsulation efficiency values. This could be as related ${ }^{26}$ to the physical unfolding of $\mathrm{ZN}$ moiety at alkaline $\mathrm{pH}$ which enhance interactive sites for supported crosslinking which augment delivery, bioavailability and consequently the pharmacological profile. ${ }^{33,34}$ As explained, P5 formula was selected for extended investigations.

The images of SEM showed the morphology of the selected formula (P5). PTS-ZN NSs were appeared as discrete regular spheres with clear surfaces free of pores or cracks (Figure 1).
PTS diffusion from PTS-ZN NSs is exhibited in Figure 2. At 36 hours, PTS diffusion showed biphasic sustained permeation manner with maximum magnitude of $89.1 \pm 2.65 \%$. The sustained diffusion could be due to the hydrophobic nature of ZN. PTS diffusion showed pattern. Specifically, the diffusion exhibited initial burst action due to fast diffusion of PTS enclosed towards surface of nanospheres. After that, diffusion was slowed and expanded as PTS take prolonger pathway of more enclosed PTS in core matrix. $^{35,36}$

\section{Cytotoxicity Estimation}

Cytotoxicity estimation of PTS-ZN NSs against two cell lines exhibited distinguished amelioration of the PTS-ZN NSs antiproliferative activity in comparison of free PTS (Figure 3). In MCF7 cells, PTS-ZN NSs obtained $\mathrm{IC}_{50}$ of $4.16 \mu \mathrm{g} / \mathrm{mL}$ and reflected augmented antiproliferative action by approximately 15 -folds in comparison to free PTS $(63.1 \mu \mathrm{g} / \mathrm{mL})$. In MDA-MB361 cells, $\mathrm{IC}_{50}$ of PTSZN NSs was $11.3 \pm 0.7$ which revealed parallel ameliorated cytotoxic profile by approximately 10 -folds in comparison to free PTS. Similar enhanced toxicity to MCF7 cells was generated when $\mathrm{ZN}$ nanoparticles utilized for exemestane and resveratrol combined delivery ${ }^{37}$ and exemestane and luteolin codelivery. ${ }^{38}$ Loading of PTS in ZN NSs caused a significant augmentation of cytotoxicity. This augmented antiproliferative could be related to the nano-size obtained in the developed NSs which facilitates interaction with biomolecules on cellular level, semi-maximum encapsulation of ZN NSs and integral PTS diffusion. ${ }^{39,40}$ Cytotoxic effect of ZN is studied against MCF7, MDA-MB361 and MDA-MB231 cells. ${ }^{13,19,41,42}$ The obtained ZN cytotoxicity may illustrate the superior proliferation-inhibiting activity of PTS-ZN NSs formula and consequently global

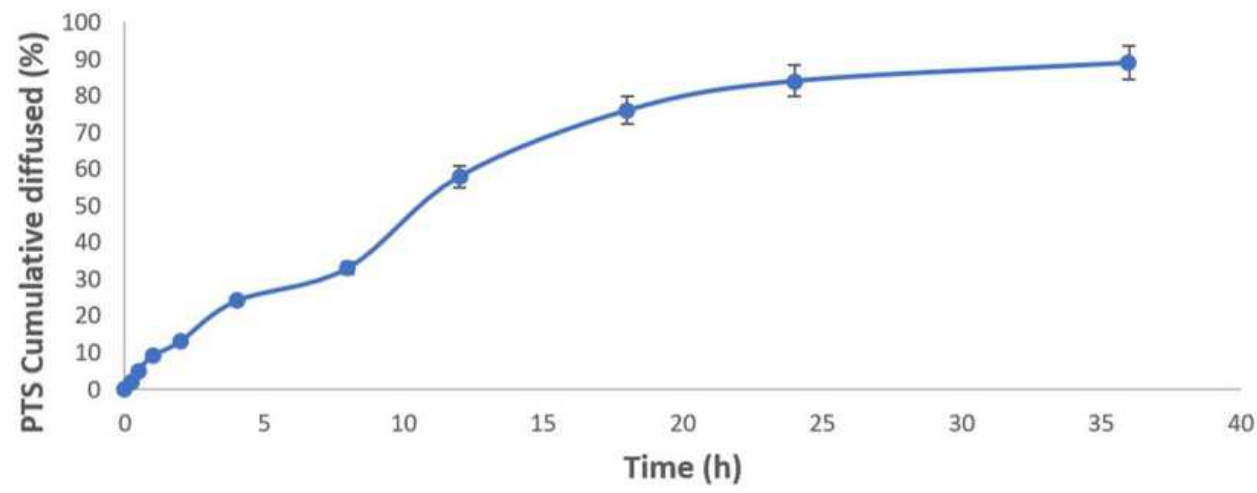

Figure 2 In vitro diffusion of PTS-ZN NSs. Data expressed as means \pm SD $(n=6)$. 


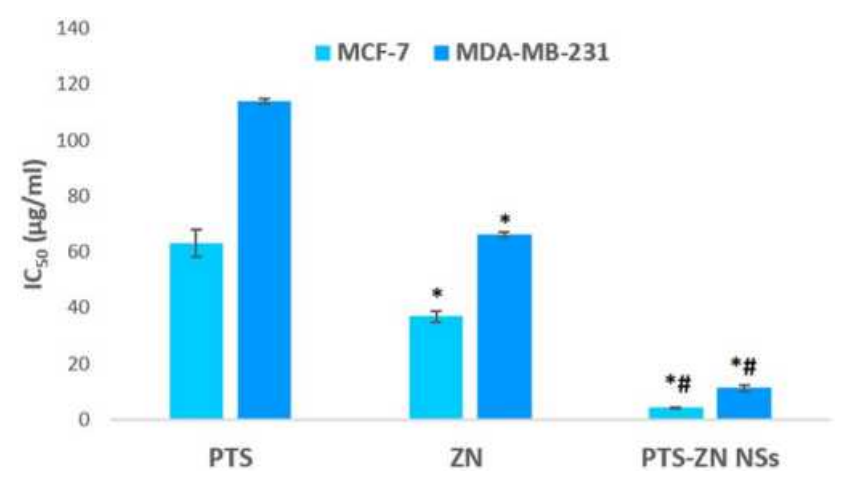

Figure $3 \mathrm{IC}_{50}$ estimation of PTS-ZN NSs against MCF7 and MDA-MB23 I cell lines. Dara presented as means \pm SD $(n=6)$.

Notes: ${ }^{*} p<0.05$ vs Pts; ${ }^{\#}<<0.05$ vs ZN.

health benefits in treating breast cancer. MCF7 cells were selected for further assays of PTS-ZN NSs due to the highest obtained antiproliferative activity.

\section{Cellular Uptake Analysis}

Figure 4 shows exhibited MCF7 cellular uptake of PTS and PTS-ZN NSs after exposing MCF7 cells to $\mathrm{IC}_{50}$ value of PTS and equivalent amount of PTS-ZN NSs. The results of free PTS uptake were estimated as $14.5 \pm 0.6 \%$ and $31.6 \pm 1.3 \%$ at 2 and 4 hours after initiating of incubation, respectively. Ameliorated PTS uptake was generated with PTS-ZN NSs treatment, which yielded $31.9 \pm 2.2 \%$ and $60.7 \pm 4.2 \%$ at after 2 and 4 hours of incubation, respectively. As clear, significant ameliorated PTS cellular uptake by PTS-ZN NSs was obtained in comparison with free PTS. This confirmed the promising functionality of $\mathrm{ZN}$ as effective biomaterial for augmentation of antiproliferative activity and improved cellular uptake. Regarding to nanocomposites particle size, it was concluded that cellular uptake of polymeric nanoparticles of $<200 \mathrm{~nm}$

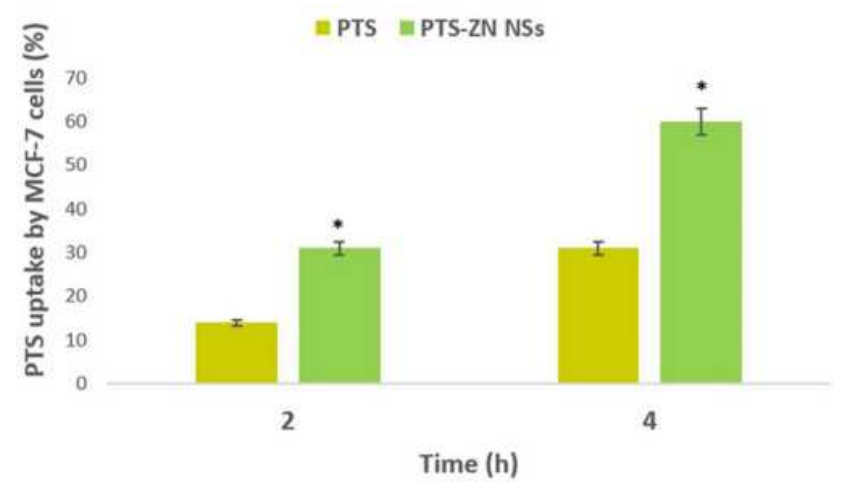

Figure 4 MCF7-cell uptake of PTS at 2 and 4 hours. Note: $* p<0.05$. mean diameter is recognized by mechanism of endocytosis. ${ }^{43}$ Positively charged nanostructures yielded an enhanced rate of membrane internalization compared to negatively charged ones. ${ }^{19}$ Also, the controlled PTS diffusion might have contributed to this result. Ability of $\mathrm{ZN}$ nano-sized dispersions to enhance cellular uptake of variant therapeutics like vorinostat and bortezomib, ${ }^{44}$ hydroxycamptothecin ${ }^{45}$ and methotrexate ${ }^{46}$ was investigated. The ameliorated internalization was correlated to enhanced adsorptive-mediated transcytosis stimulated by electrostatic interaction between $\mathrm{ZN}$ positively charged moieties and negatively charged cellular membrane. ${ }^{19,47}$

\section{Cell Cycle Progression Analysis}

Fast growth was obtained in MCF7 untreated control cells, with $56.44 \pm 3.2 \%, \quad 38.15 \pm 2.3 \%, \quad 5.41 \pm 1.2 \%$ and 1.53 $\pm 0.06 \%$ at the $\mathrm{G} 0 / \mathrm{G} 1$ phase, $\mathrm{S}$ phase, G2-M phase, and pre-G1 phase, respectively (Figure 5A). Other incubations related to PTS, ZN and PTS-ZN NSs groups exhibited reduced proliferation and yielded accumulation of MCF7 cells in $\mathrm{G} 0 / \mathrm{G} 1$ and pre-G phases (Figure 5B-D). PTS Ability to induce apoptosis and cell cycle arrest in both Bcap-37 and MCF7 cell lines was demonstrated. ${ }^{48,49}$ Also, PTS has been shown to cause a transient accumulation of cells in the $G_{0} / G_{1}$-cell cycle phase followed by the S-phase arrest in MOLT4 human leukemia cells. ${ }^{50}$ Almost the same observations were reported by ${ }^{10}$ PTS-induced apoptosis due to ROS generation in MCF7 and nitric oxide over production in PC3 cells. It was concluded previously that PTS exerted its anticancer action in breast cancer by arresting cells in $\mathrm{G} 0 / \mathrm{G} 1, \mathrm{G} 2 / \mathrm{M}$ or $\mathrm{S}$ phase. ${ }^{51}$ Also, it was reported that PTS primary mechanism is mitochondrial-dependent apoptosis via the release of Smac/ DIABLO in conjunction with cytochrome $C^{51,52}$ PTS anticancer activities are postulated to be related to hydroxylated stilbene moiety that was able to develop hydrogenbonds and stable resonance structures in the biological system. ${ }^{53}$ Accumulation values of cells in pre-G phase was estimated as $11.38 \pm 0.5 \%, 13.59 \pm 1.1 \%$, and 27.52 $\pm 1.9 \%$ for PTS, ZN, and PTS-ZN NSs incubations, respectively. Graphical statistics of changes in cell cycle phases are presented in Figure 5E.

\section{Annexin V Staining Assay}

For additional revealing of apoptotic action, control, PTS, ZN and PTS-ZN NSs incubations were subjected to positive annexin $\mathrm{V}$ staining analysis (Figure 6A-D). PTS-ZN NSs enhanced to a great extent early, late, and total cell death compared to all of other incubations. Figure $6 \mathrm{E}$ 

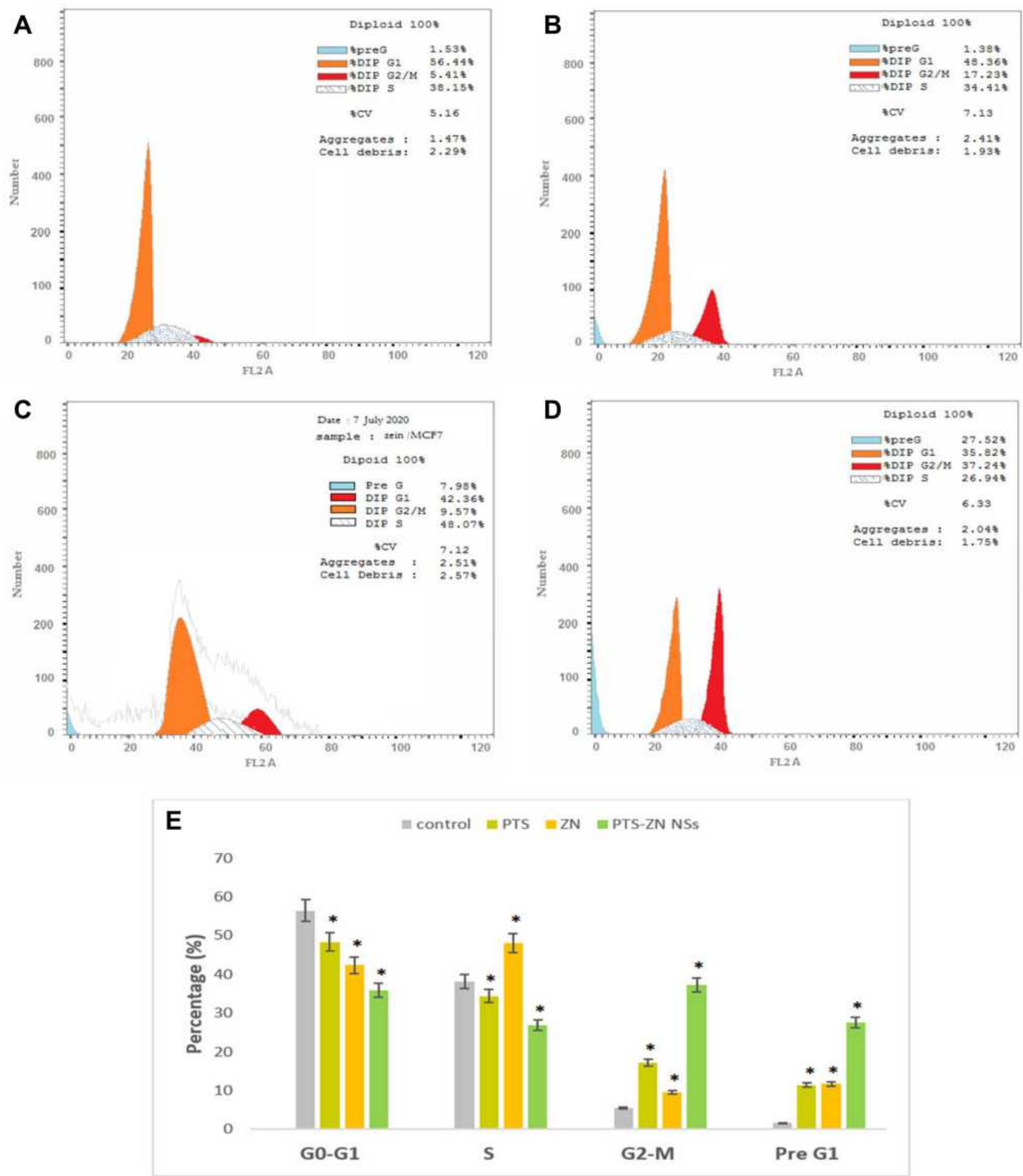

Figure 5 PTS-ZN NS impact on cell-cycle phases. (A) Control; (B) PTS; (C) ZN; (D) PTS-ZN NSs; (E) graphic representation of each phase. Note: $* p<0.05$ vs control.

displayed graphical presentation for each type of cell death. PTS-ZN NSs obtained the most potent action in ameliorating pre-G phase that illustrates apoptotic cell death. Additional confirmation was carried out by annexin
V staining, which displayed the highest apoptotic-enhancing action of ZN in the PTS-ZN NPSs compared to free PTS. This was an evidence of early and late apoptotic death, in addition to total cell death. The generated results 
A

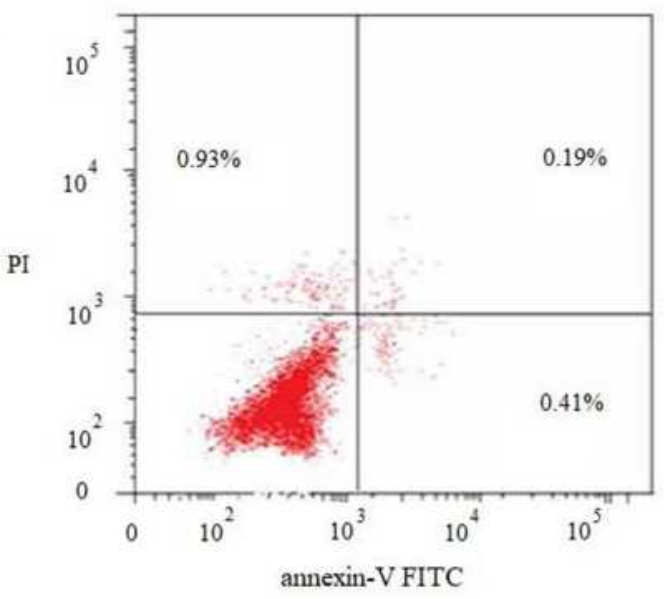

C

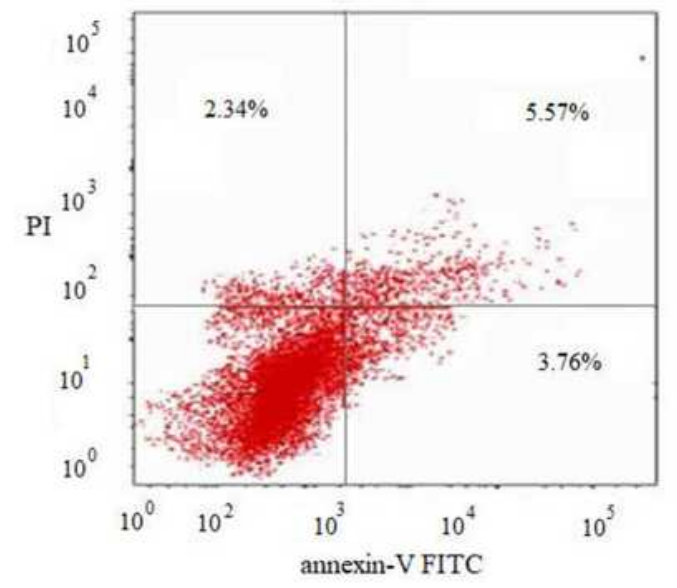

B

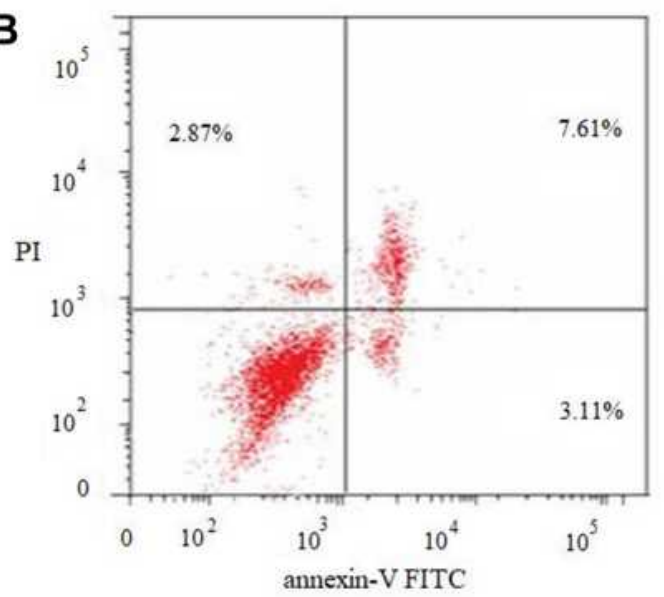

D

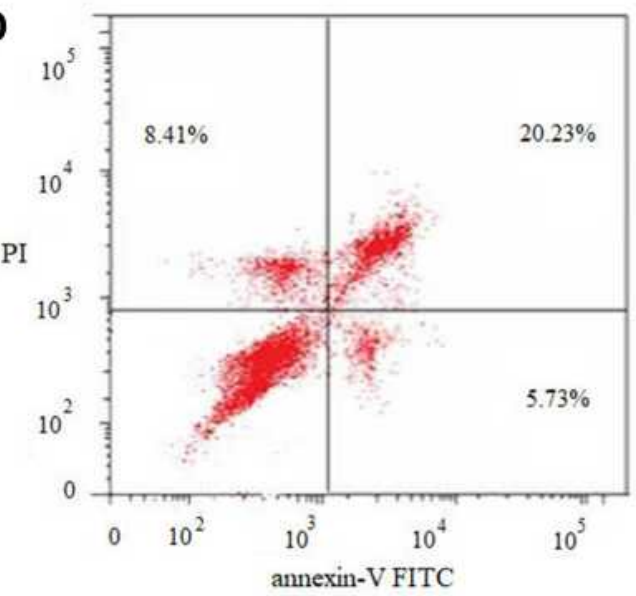

E

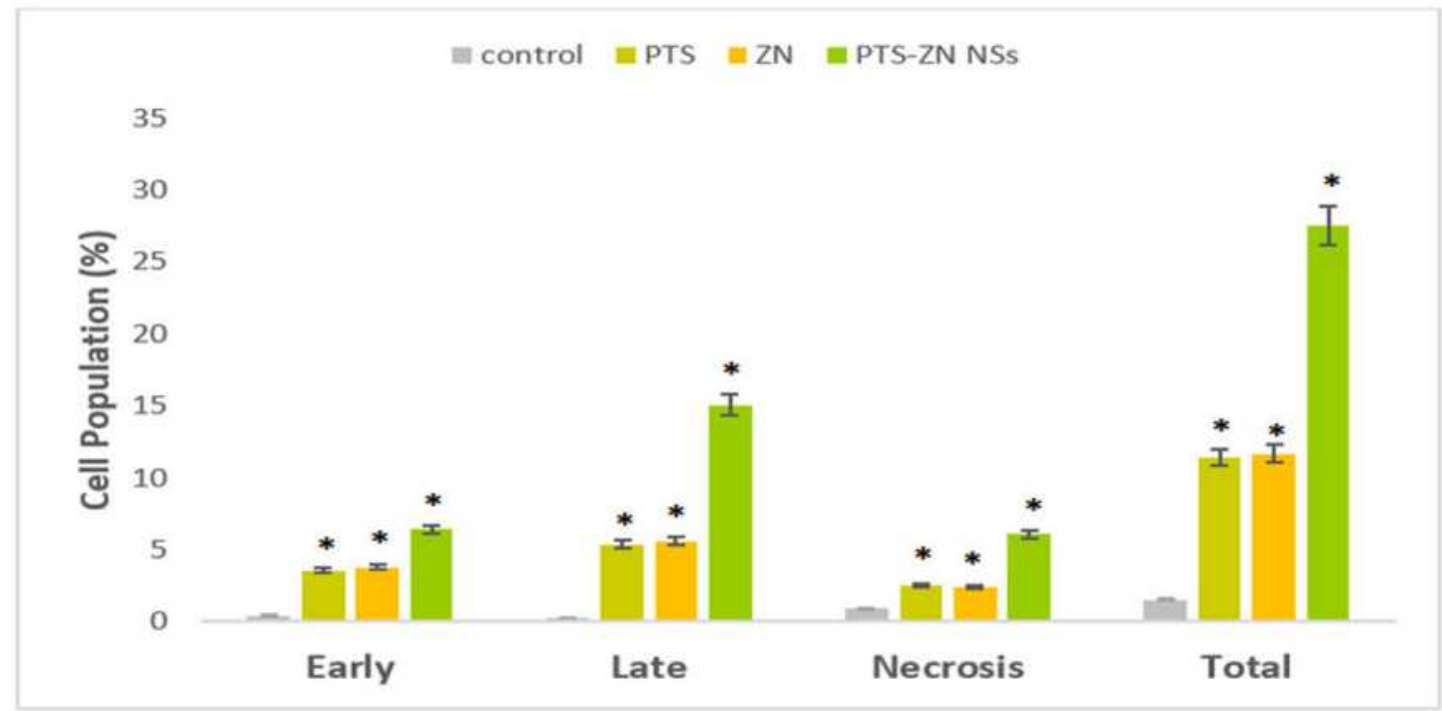

Figure 6 PTS-ZN NS impact on annexin V-FITC positive staining of MCF7 cells. (A) Control; (B) PTS; (C) ZN; (D) PTS-ZN NSs; (E) graphic representation of early and late apoptotic, necrotic, and total cell death.

Note: $* p<0.05$ vs control. 
were in accordance with previous works examining PTS effect on cell cycle phases. ${ }^{54}$ PTS capacity to stimulate apoptosis was illustrated as revealed by increasing annexin V staining of T24, T24R cells ${ }^{55}$ and HL-60 cells. ${ }^{56}$

\section{mRNA Expression of Apoptotic Genes}

Figure 7 displays the statistically variant ratios of gene expression of two proapoptotic genes (CASP3 and CASP7) and one anti-apoptotic gene (CDK1) of PTS-ZN NSs treated cells. PTS-ZN NSs obtained the highest expression of CASP3, CASP7 and CDK1 genes for MCF7 cells compared to free PTS. ZN-NSs ameliorated the expression of the utilized apoptotic markers, which confirmed synergistic anticancer profile in the treated cells.

CASP3 activation is essential for apoptosis induction mediated by chemotherapeutic drugs; thus, it can be used to predict cancer cells sensitivity to chemotherapeutic agents. PTS, ZN and PTS-ZN NSs groups obtained folds change of 2.37, 3.54 and 4.2, respectively. PTS-ZN NSs generated enhanced apoptotic action compared in comparison to untreated positive control. PTS-ZN NSs obtained 1.77-fold raising in CASP3 level in comparison to free PTS. Caspases initiate apoptosis process to control cell regulatory function which was essentially considered a critical feature of therapeutics that target cancer. $^{57}$ CASP3 insufficiency might be the reason for MCF7 cells insensitivity to many chemotherapeutic agents. ${ }^{58}$

Although the overlapping incidence of CASP3 and CASP7, they also have distinct roles in apoptosis. ${ }^{59}$ Regrading to importance of caspases, CASP7 expression was studied also. Several substrates are selectively cleaved by CASP7. ${ }^{59}$ PTS, ZN and PTS-ZN NSs treated groups displayed folds change of 4.54, 5.89 and 11.61, respectively. PTS-ZN NSs generated raised apoptotic action in comparison to untreated positive control. PTS-ZN NSs obtained 2.55-fold increase in caspase 7 level in comparison to free PTS. Our results concluded that caspases are decisive for apoptosis progression when breast cancer MCF7 cells are exposed to PTS.

PTS, ZN and PTS-ZN NSs treated groups of CDK1 expression exhibited 0.46, 0.4 and 0.24-folds change, respectively. PTS-ZN NSs exhibited higher apoptotic effect in comparison to untreated positive control. PTSZN NSs revealed 1.9-fold decrease in CDK1 level compared with free PTS. These results confirmed the apoptotic role of PTS in cancer progression through modulation of

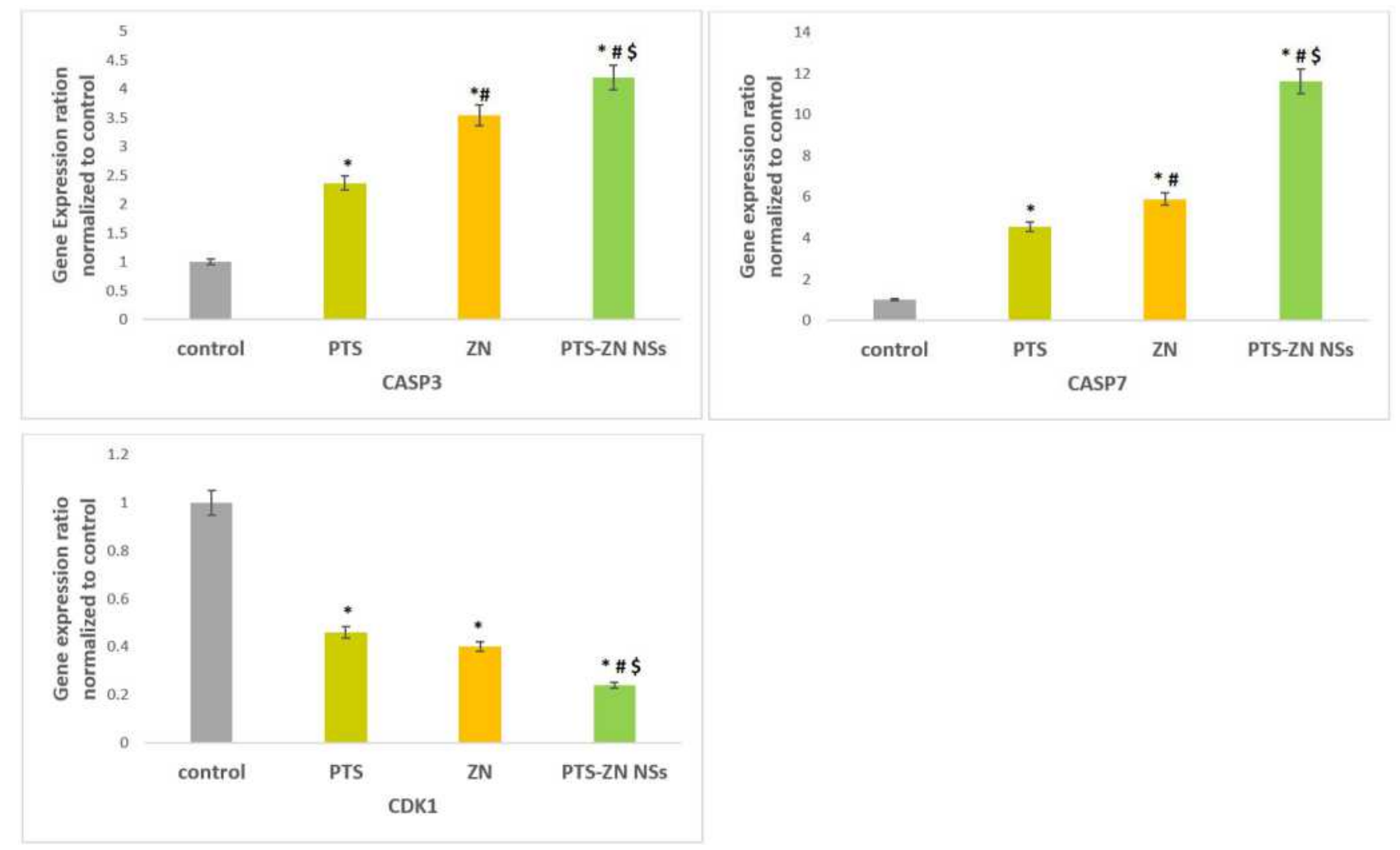

Figure 7 PTS-ZN NS impact on mRNA expression of CASP3, CASP7, and CDKI in MCF7 cells. Notes: ${ }^{*} p<0.05$ vs control; ${ }_{p}^{*}<0.05$ vs Pts; ${ }_{p} p<0.05$ vs $Z \mathrm{~N}$. 
CDK1. The down-regulated CDK1 activity might be give rise to broken $\mathrm{G} 2 / \mathrm{M}$ progression which affect mainly DNA damage-induced apoptosis as reported by. ${ }^{60}$ Regarding to the known role of cyclin-dependent kinases in controlling progression of cell cycle from $\mathrm{G} 2$ to $\mathrm{M}$ phase, ${ }^{61} \mathrm{CDKs}$ dysregulation is related to formation of different tumors especially breast cancer. ${ }^{62}$

As a conclusion, our study indicated that apoptosis in MCF7 cells was confirmed and augmented through caspases dependent signaling pathways and inhibition of CDK1 activity due to use of ZN-NSs in delivery of PTS in comparison with free PTS.

\section{Oxidative Stress}

Contribution of free radicals to carcinogenesis through DNA damage and lipid peroxidation. Table 3 displays the results of oxidative stress. PTS-ZN NSs significantly inhibited GR activity by $34.8 \%$ in comparison to control and PTS (10.37\%). The PTS ability to enhance expression of antioxidants catalase, total glutathione, glutathione peroxidase, glutathione reductase was reported due to involvement in initiation and pathogenesis of multiple disease processes. $^{63,64}$ Due to the recognized role of ROS in apoptosis induction, ${ }^{65}$ It was concluded that PTS may generated raised ROS which in turn catalyse the intrinsic apoptotic pathway due to direct action on the mitochondrial membrane. ${ }^{66}$ Generation of ROS was estimated by DCFH-DA. PTS-ZN NSs had the largest capacity of green fluorescence. ROS production was increased by 1.37 -folds after incubation with PTS-ZN NSs as a possible fate of singlet oxygen or hydrogen peroxide production thus causing apoptosis related to PTS cytotoxicity. ${ }^{10}$ PTS stilbene deforms the ionic balance of the mitochondria which is required for cancer cell growth progression. ${ }^{44}$ It was revealed that the anti-peroxidative effects of hydroxylated resveratrol molecules including PTS could be due related to the phenolic groups that can scavenge lipid hydroperoxyl, hydroxyl and superoxide anion. ${ }^{67}$ Also, PTS generates its anticancer activity through ROS levels regulation, which stimulates downstream signaling pathways as antioxidant or prooxidant. ${ }^{68,69}$ Also, PTS and PTS-ZN NSs reduced MDA levels significantly by $16.48 \%$ and $30.27 \%$ compared to control values, respectively. Increasing in MDA levels was verification for suppression of lipid peroxidation ${ }^{70}$ that extended oxidative stress activity due to utilization of $\mathrm{ZN} \mathrm{NSs.}$

As a conclusion, our study indicated that oxidative stress potential in MCF7 cells was confirmed and augmented through reduction of GR activity and MDA level in addition to increasing ROS formation due to use of $\mathrm{ZN}$ NSs in delivery of PTS in comparison with free PTS.

\section{Stability Study}

Colloidal stability of the fabricated PTS-Zn NSs was expressed by investigation of the average particle size related to NSs incubation samples in FBS (Figure 8). PTS-ZN NSs exhibited initial increase of the average particle size in the first few hours and then reduced to non-significant increased value. The prepared nanocomposites indicate satisfied stability profile in serum that recommend there use in in vitro and in vivo protocols without considering the possible effect of interacting with biomolecules on colloidal environment of nanocomposites.

\section{Conclusion}

The present study revealed that PTS-ZN NSs generated ameliorated antiproliferative, proapoptotic and oxidative stress potentials against MCF7 cells compared to free PTS. Promising research outcomes included nanocomposites with high encapsulation efficiency, 36 hours extended PTS diffusion, a synergized cytotoxicity profile, enhanced MCF7 cells uptake, ameliorated apoptosis induced potential, enhanced mRNA expression of CASP3, CASP7 and CDK1 genes and significant oxidative stress. This is mediated, at least partly, by influential functionalization of $\mathrm{ZN}$ as candidate for

Table 3 Oxidative stress estimation of PTS-ZN NSs

\begin{tabular}{|l|l|l|l|}
\hline & GR $\left(\mu \mathrm{U} / 10^{6}\right.$ cells) & ROS (pg/1 $0^{6}$ cells) & MDA (nmoLI/106 cells) \\
\hline Control & $1.64 \pm 0.11$ & $100.21 \pm 7.39$ & $1.58 \pm 0.13$ \\
PTS & $1.47^{*} \pm 0.09$ & $126.34^{*} \pm 10.18$ & $1.82^{*} \pm 0.09$ \\
ZN & $1.55 \pm 0.38$ & $102.44 \pm 11.92$ & $1.66 \pm 0.21$ \\
PTS-ZN NSs & $1.07 \pm 0.04^{* \# \$}$ & $166.83 \pm 9.65^{* \# \$}$ & $2.53^{* \# \$} \pm 0.14$ \\
\hline
\end{tabular}

Notes: Results expressed as means \pm SD ( $=6$ ). $p<0.05$ vs control; ${ }^{\#}$ significantly different than Pts $p<0.05$ vs Pts; ${ }^{\$}<0.05$ vs Zn. 


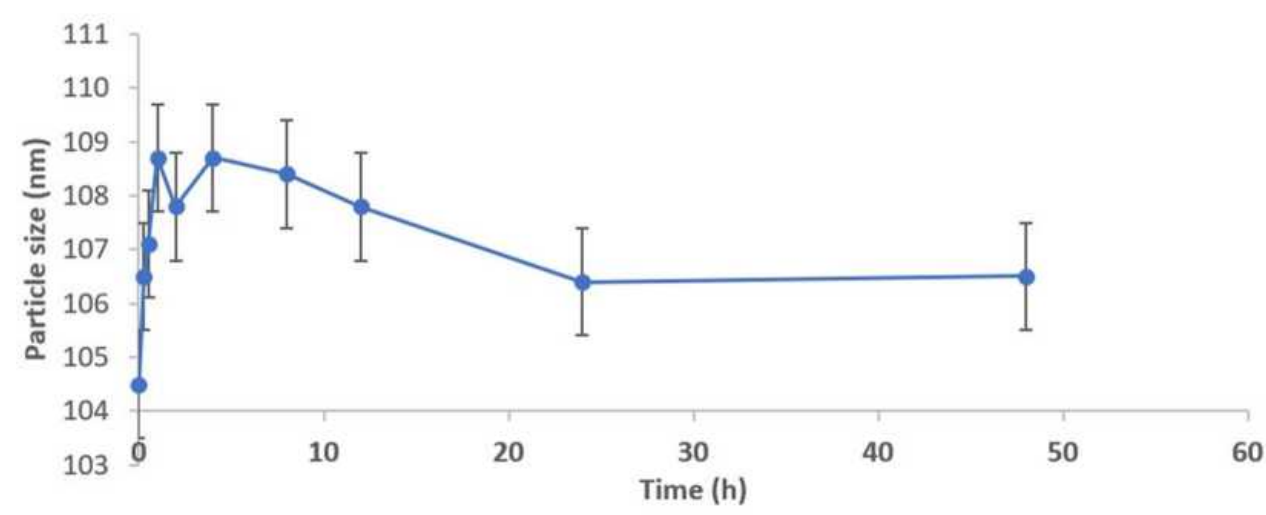

Figure 8 PTS-ZN NS serum-stability estimation.

successful delivery and supporting of pharmacotherapeutic profile of PTS against MCF7 cells.

\section{Acknowledgments}

This project was funded by the Deanship of Scientific Research (DSR), King Abdulaziz University, Jeddah, Saudi Arabia, under grant G: 590-166-1441. The authors acknowledge with thanks the DSR for technical and financial support.

\section{Author Contributions}

All authors contributed significantly to the study in all stages of conception, study design, execution, acquisition of data, analysis, drafting, interpretation, and final approval of the manuscript. All authors agreed on the journal to which the article has been submitted, and agree to be accountable for all parts of this study.

\section{Disclosure}

The authors declare no conflicts of interest.

\section{References}

1. Hassan M, Watari H, AbuAlmaaty A, Ohba Y, Sakuragi N. Apoptosis and molecular targeting therapy in cancer. Biomed Res Int. 2014;2014:1-23. doi:10.1155/2014/150845

2. Gerl R. Apoptosis in the development and treatment of cancer. Carcinogenesis. 2004;26(2):263-270. doi:10.1093/carcin/bgh283

3. Brown JM, Attardi LD. The role of apoptosis in cancer development and treatment response. Nat Rev Cancer. 2005;5(3):231-237. doi: $10.1038 / \mathrm{nrc} 1560$

4. Kim R, Emi M, Tanabe K. The role of apoptosis in cancer cell survival and therapeutic outcome. Cancer Biol Ther. 2006;5(11):1429-1442. doi:10.4161/cbt.5.11.3456

5. Harbeck N. Breast cancer is a systemic disease optimally treated by a multidisciplinary team. Nat Rev Dis Primers. 2020;6(1):1-2. doi:10.1038/s41572-020-0167-z
6. Shi J, Kantoff PW, Wooster R, Farokhzad OC. Cancer nanomedicine: progress, challenges and opportunities. Nat Rev Cancer. 2017;17 (1):20.

7. Kasibhatla S, Tseng B. Why target apoptosis in cancer treatment? Mol Cancer Ther. 2003;2(6):573-580.

8. Pezzuto JM, Vang O. Natural Products for Cancer Chemoprevention. Springer; 2020.

9. Chakraborty A, Bodipati N, Demonacos MK, Peddinti R, Ghosh K, Roy $\mathrm{P}$. Long term induction by pterostilbene results in autophagy and cellular differentiation in MCF-7 cells via ROS dependent pathway. Mol Cell Endocrinol. 2012;355(1):25-40. doi:10.1016/j.mce.2012.01.009

10. Chakraborty A, Gupta N, Ghosh K, Roy P. In vitro evaluation of the cytotoxic, anti-proliferative and anti-oxidant properties of pterostilbene isolated from Pterocarpus marsupium. Toxicol Vitro. 2010;24 (4):1215-1228. doi:10.1016/j.tiv.2010.02.007

11. Levenson AS, Kumar A. Pterostilbene as a Potent Chemopreventive Agent in Cancer. In: Natural Products for Cancer Chemoprevention. Springer; 2020:49-108.

12. Aqil F, Munagala R, Jeyabalan J, Vadhanam MV. Bioavailability of phytochemicals and its enhancement by drug delivery systems. Cancer Lett. 2013;334(1):133-141. doi:10.1016/j.canlet.2013.02.032

13. Prasad R, Pandey R, Varma R, Barman I. Polymer based nanoparticles for drug delivery systems and cancer therapeutics. In: Natural Polymers for Drug Delivery. Oxfordshire. CABI; 2016:53-70.

14. Qi -S-S, Sun J-H, Yu -H-H, Yu S-Q. Co-delivery nanoparticles of anti-cancer drugs for improving chemotherapy efficacy. Drug Deliv. 2017;24(1):1909-1926. doi:10.1080/10717544.2017.1410256

15. Abd-Rabou AA, Bharali DJ, Mousa SA. Taribavirin and 5-fluorouracil-loaded pegylated-lipid nanoparticle synthesis, p38 docking, and antiproliferative effects on MCF-7 breast cancer. Pharm Res. 2018;35 (4):76. doi:10.1007/s11095-017-2283-3

16. Corsi F, Fiandra L, De Palma C, et al. HER2 expression in breast cancer cells is downregulated upon active targeting by antibodyengineered multifunctional nanoparticles in mice. ACS Nano. 2011;5(8):6383-6393. doi:10.1021/nn201570n

17. Godugu K, El-Far AH, Al Jaouni S, Mousa SA. Nanoformulated Ajwa (Phoenix Dactylifera) bioactive compounds improve the safety of doxorubicin without compromising its anticancer efficacy in breast cancer. Molecules. 2020;25(11):2597. doi:10.3390/molecules 25112597

18. Hild W, Pollinger K, Caporale A, et al. G protein-coupled receptors function as logic gates for nanoparticle binding and cell uptake. Proc Nat Acad Sci. 2010;107(23):10667-10672. doi:10.1073/ pnas.0912782107

19. Algandaby MM, Al-Sawahli MM. Augmentation of anti-proliferative, pro-apoptotic and oxidant profiles induced by piceatannol in human breast carcinoma MCF-7 cells using zein nanostructures. Biomed Pharmacother. 2021;138:111409. doi:10.1016/j.biopha.2021. 111409 
20. Sarkar S, Ponce NT, Banerjee A, Bandopadhyay R, Rajendran S, Lichtfouse E. Green polymeric nanomaterials for the photocatalytic degradation of dyes: a review. Environ Chem Lett. 2020;1-12. doi:10.1007/s10311-020-01021-w

21. De Matteis V, Rizzello L, Ingrosso C, et al. Cultivar-dependent anticancer and antibacterial properties of silver nanoparticles synthesized using leaves of different Olea Europaea trees. Nanomaterials. 2019;9(11):1544. doi:10.3390/nano9111544

22. Zhang Q, Wang J, Liu D, et al. Targeted delivery of honokiol by zein/ hyaluronic acid core-shell nanoparticles to suppress breast cancer growth and metastasis. Carbohydr Polym. 2020;240:116325. doi:10.1016/j.carbpol.2020.116325

23. Cheng CJ, Jones OG. Stabilizing zein nanoparticle dispersions with tcarrageenan. Food Hydrocoll. 2017;69:28-35. doi:10.1016/j. foodhyd.2017.01.022

24. Ahmed OA, Hosny KM, Al-Sawahli MM, Fahmy UA. Optimization of caseinate-coated simvastatin-zein nanoparticles: improved bioavailability and modified release characteristics. Drug Des Devel Ther. 2015;9:655. doi:10.2147/DDDT.S76194

25. Algandaby MM, Al-Sawahli MM, Ahmed OA, et al. Curcumin-zein nanospheres improve liver targeting and antifibrotic activity of curcumin in carbon tetrachloride-induced mice liver fibrosis. J Biomed Nanotechnol. 2016;12(9):1746-1757. doi:10.1166/jbn.2016.2270

26. Lai L, Guo H. Preparation of new 5-fluorouracil-loaded zein nanoparticles for liver targeting. Int $J$ Pharm. 2011;404(1-2):317-323. doi:10.1016/j.ijpharm.2010.11.025

27. Lin HS, Yue BD, Ho PC. Determination of pterostilbene in rat plasma by a simple HPLC-UV method and its application in pre-clinical pharmacokinetic study. Biomed Chromatogr. 2009;23(12):13081315. doi:10.1002/bmc. 1254

28. Seyed MA, Jantan I, Bukhari SNA, Vijayaraghavan K. A comprehensive review on the chemotherapeutic potential of piceatannol for cancer treatment, with mechanistic insights. J Agric Food Chem. 2016;64(4):725-737. doi:10.1021/acs.jafc.5b05993

29. Gagliardi A, Paolino D, Iannone M, Palma E, Fresta M, Cosco D. Sodium deoxycholate-decorated zein nanoparticles for a stable colloidal drug delivery system. Int J Nanomedicine. 2018;13:601. doi:10.2147/IJN.S156930

30. Reddy N, Yang Y. Potential of plant proteins for medical applications. Trends Biotechnol. 2011;29(10):490-498. doi:10.1016/j. tibtech.2011.05.003

31. Canon F, Giuliani A, Paté F, Sarni-Manchado P. Ability of a salivary intrinsically unstructured protein to bind different tannin targets revealed by mass spectrometry. Anal Bioanal Chem. 2010;398 (2):815-822. doi:10.1007/s00216-010-3997-9

32. Hashem FM, Al-Sawahli MM, Nasr M, Ahmed OA. Optimized zein nanospheres for improved oral bioavailability of atorvastatin. Int $J$ Nanomedicine. 2015;10:4059. doi:10.2147/IJN.S83906

33. Liversidge GG, Cundy KC. Particle size reduction for improvement of oral bioavailability of hydrophobic drugs: i. Absolute oral bioavailability of nanocrystalline danazol in beagle dogs. Int J Pharm. 1995;125(1):91-97. doi:10.1016/0378-5173(95)00122-Y

34. Petros RA, DeSimone JM. Strategies in the design of nanoparticles for therapeutic applications. Nat Rev Drug Discov. 2010;9(8):615627. doi:10.1038/nrd2591

35. Lee JH, Yeo Y. Controlled drug release from pharmaceutical nanocarriers. Chem Eng Sci. 2015;125:75-84. doi:10.1016/j. ces.2014.08.046

36. Padua GW, Wang Q. Controlled Self-Organization of Zein Nanostructures for Encapsulation of Food Ingredients. ACS Publications; 2009.

37. Elzoghby AO, El-Lakany SA, Helmy MW, Abu-Serie MM, Elgindy NA. Shell-crosslinked zein nanocapsules for oral codelivery of exemestane and resveratrol in breast cancer therapy. Nanomedicine. 2017;12(24):2785-2805. doi:10.2217/nnm-2017-0247
38. El-Lakany SA, Elgindy NA, Helmy MW, Abu-Serie MM, Elzoghby AO. Lactoferrin-decorated vs PEGylated zein nanospheres for combined aromatase inhibitor and herbal therapy of breast cancer. Expert Opin Drug Deliv. 2018;15(9):835-850. doi:10.1080/17425247.2018.1505858

39. Dhanapal J, Balaraman Ravindrran M. Chitosan/poly (lactic acid)coated piceatannol nanoparticles exert an in vitro apoptosis activity on liver, lung and breast cancer cell lines. Artif Cells, Nanomed Biotechnol. 2018;46(sup1):274-282. doi:10.1080/ 21691401.2017.1422130

40. Oberdörster G, Maynard A, Donaldson K, et al. Principles for characterizing the potential human health effects from exposure to nanomaterials: elements of a screening strategy. Part Fibre Toxicol. 2005;2(1):8. doi:10.1186/1743-8977-2-8

41. Alhakamy NA, Ahmed OA, Aldawsari HM, et al. Encapsulation of lovastatin in zein nanoparticles exhibits enhanced apoptotic activity in HepG2 cells. Int J Mol Sci. 2019;20(22):5788. doi:10.3390/ ijms 20225788

42. Xu H, Jiang Q, Reddy N, Yang Y. Hollow nanoparticles from zein for potential medical applications. J Mater Chem. 2011;21(45):1822718235. doi: $10.1039 / \mathrm{c} 1 \mathrm{jm} 11163 \mathrm{a}$

43. Conner SD, Schmid SL. Regulated portals of entry into the cell. Nature. 2003;422(6927):37-44. doi:10.1038/nature01451

44. Thapa RK, Nguyen HT, Jeong J-H, et al. Synergistic anticancer activity of combined histone deacetylase and proteasomal inhibitorloaded zein nanoparticles in metastatic prostate cancers. Nanomedicine. 2017;13(3):885-896. doi:10.1016/j.nano.2016.12.010

45. Wang H, Zhu W, Huang Y, Li Z, Jiang Y, Xie Q. Facile encapsulation of hydroxycamptothecin nanocrystals into zein-based nanocomplexes for active targeting in drug delivery and cell imaging. Acta biomater. 2017;61:88-100. doi:10.1016/j.actbio.2017.04.017

46. Jain A, Sharma G, Kushwah V, et al. Beta carotene-loaded zein nanoparticles to improve the biopharmaceutical attributes and to abolish the toxicity of methotrexate: a preclinical study for breast cancer. Artif Cells Nanomed Biotechnol. 2018;46(sup1):402-412. doi:10.1080/21691401.2018.1428811

47. Kanwar JR, Samarasinghe RM, Sehgal R, Kanwar RK. Nano-lactoferrin in diagnostic, imaging and targeted delivery for cancer and infectious diseases. J Cancer Sci Ther. 2012;4(3):31-42. doi:10.4172/ 1948-5956.1000107

48. Nikhil K, Sharan S, Chakraborty A, Bodipati N, Peddinti RK, Roy P. Role of isothiocyanate conjugate of pterostilbene on the inhibition of MCF-7 cell proliferation and tumor growth in Ehrlich ascitic cell induced tumor bearing mice. Exp Cell Res. 2014;320(2):311-328. doi:10.1016/j.yexcr.2013.10.015

49. Wang Y, Ding L, Wang X, et al. Pterostilbene simultaneously induces apoptosis, cell cycle arrest and cyto-protective autophagy in breast cancer cells. Am J Transl Res. 2012;4(1):44.

50. Siedlecka-Kroplewska K, Jozwik A, Kaszubowska L, Kowalczyk A, Boguslawski W. Pterostilbene induces cell cycle arrest and apoptosis in MOLT4 human leukemia cells. Folia Histochemica Et Cytobiologica. 2012;50(4):574-580. doi:10.5603/FHC.2012.0080

51. Daniel M, Tollefsbol TO. Pterostilbene down-regulates hTERT at physiological concentrations in breast cancer cells: potentially through the inhibition of cMyc. J Cell Biochem. 2018;119(4):33263337. doi: $10.1002 / \mathrm{jcb} .26495$

52. Moon D, McCormack D, McDonald D, McFadden D. Pterostilbene induces mitochondrially derived apoptosis in breast cancer cells in vitro. J Surg Res. 2013;180(2):208-215. doi:10.1016/j.jss.2012.04.027

53. Stivala LA, Savio M, Carafoli F, et al. Specific structural determinants are responsible for the antioxidant activity and the cell cycle effects of resveratrol. J Biol Chem. 2001;276(25):22586-22594. doi:10.1074/jbc.M101846200

54. Pan C, Hu Y, Li J, et al. Estrogen receptor- $\alpha 36$ is involved in pterostilbene-induced apoptosis and anti-proliferation in in vitro and in vivo breast cancer. PLoS One. 2014;9(8):e104459. doi:10.1371/ journal.pone. 0104459 
55. Chen RJ, Ho CT, Wang YJ. Pterostilbene induces autophagy and apoptosis in sensitive and chemoresistant human bladder cancer cells. Mol Nutr Food Res. 2010;54(12):1819-1832. doi:10.1002/ mnfr.201000067

56. Hsiao P-C, Chou Y-E, Tan P, et al. Pterostilbene simultaneously induced G0/G1-phase arrest and MAPK-mediated mitochondrialderived apoptosis in human acute myeloid leukemia cell lines. PLoS One. 2014;9(8):e105342. doi:10.1371/journal.pone.0105342

57. Shinde P, Agraval H, Srivastav AK, Yadav UC, Kumar U. Physicochemical characterization of carvacrol loaded zein nanoparticles for enhanced anticancer activity and investigation of molecular interactions between them by molecular docking. Int $J$ Pharm. 2020;588:119795. doi:10.1016/j.ijpharm.2020.119795

58. Devarajan E, Sahin AA, Chen JS, et al. Down-regulation of caspase 3 in breast cancer: a possible mechanism for chemoresistance. Oncogene. 2002;21(57):8843-8851. doi:10.1038/sj.onc.1206044

59. Lamkanfi M, Kanneganti T-D. Caspase-7: a protease involved in apoptosis and inflammation. Int J Biochem Cell Biol. 2010;42 (1):21-24. doi:10.1016/j.biocel.2009.09.013

60. Huang -W-W, Ko S-W, Tsai H-Y, et al. Cantharidin induces G2/M phase arrest and apoptosis in human colorectal cancer colo 205 cells through inhibition of CDK1 activity and caspase-dependent signaling pathways. Int $J$ Oncol. 2011;38(4):1067-1073. doi:10.3892/ ijo. 2011.922

61. Chen S, Chen X, Xiu Y-L, Sun K-X, Zhao Y. MicroRNA-490-3P targets CDK1 and inhibits ovarian epithelial carcinoma tumorigenesis and progression. Cancer Lett. 2015;362(1):122-130. doi:10.1016/j. canlet.2015.03.029

62. Ding L, Cao J, Lin W, et al. The roles of cyclin-dependent kinases in cell-cycle progression and therapeutic strategies in human breast cancer. Int J Mol Sci. 2020;21(6):1960. doi:10.3390/ijms21061960
63. Chen R-J, Kuo H-C, Cheng L-H, et al. Apoptotic and nonapoptotic activities of pterostilbene against cancer. Int J Mol Sci. 2018;19 (1):287. doi:10.3390/ijms19010287

64. McCormack D, McFadden D. A review of pterostilbene antioxidant activity and disease modification. Oxid Med Cell Longev. 2013;2013:1-15. doi:10.1155/2013/575482

65. Jj LI, Tang Q, Li Y, et al. Role of oxidative stress in the apoptosis of hepatocellular carcinoma induced by combination of arsenic trioxide and ascorbic acid 1. Acta Pharmacol Sin. 2006;27(8):1078-1084. doi:10.1111/j.1745-7254.2006.00345.x

66. Alosi JA, McDonald DE, Schneider JS, Privette AR, McFadden DW. Pterostilbene inhibits breast cancer in vitro through mitochondrial depolarization and induction of caspase-dependent apoptosis. J Surg Res. 2010;161(2):195-201. doi:10.1016/j.jss.2009.07.027

67. Murias M, Jäger W, Handler N, et al. Antioxidant, prooxidant and cytotoxic activity of hydroxylated resveratrol analogues: structureactivity relationship. Biochem Pharmacol. 2005;69(6):903-912. doi:10.1016/j.bcp.2004.12.001

68. Karthikeyan S, Prasad NR, Ganamani A, Balamurugan E. Anticancer activity of resveratrol-loaded gelatin nanoparticles on NCI-H460 non-small cell lung cancer cells. Biomed Prevent Nutr. 2013;3 (1):64-73. doi:10.1016/j.bionut.2012.10.009

69. Miki H, Uehara N, Kimura A, et al. Resveratrol induces apoptosis via ROS-triggered autophagy in human colon cancer cells. Int J Oncol. 2012;40(4):1020-1028. doi:10.3892/ijo.2012.1325

70. Chen Y, Chen Y, Zhang H, Wang T. Pterostilbene as a protective antioxidant attenuates diquat-induced liver injury and oxidative stress in 21-day-old broiler chickens. Poult Sci. 2020;99(6):3158-3167. doi:10.1016/j.psj.2020.01.021
International Journal of Nanomedicine

\section{Publish your work in this journal}

The International Journal of Nanomedicine is an international, peerreviewed journal focusing on the application of nanotechnology in diagnostics, therapeutics, and drug delivery systems throughout the biomedical field. This journal is indexed on PubMed Central, MedLine, CAS, SciSearch ${ }^{\circledR}$, Current Contents ${ }^{\circledR} /$ Clinical Medicine,

\section{Dovepress}

Journal Citation Reports/Science Edition, EMBase, Scopus and the Elsevier Bibliographic databases. The manuscript management system is completely online and includes a very quick and fair peer-review system, which is all easy to use. Visit http://www.dovepress.com/ testimonials.php to read real quotes from published authors. 